\title{
MODELING CHANGES IN ORGANIC CARBON STOCKS FOR DISTINCT SOILS IN SOUTHEASTERN BRAZIL AFTER FOUR EUCALYPTUS ROTATIONS USING THE CENTURY MODEL ${ }^{(1)}$
}

\author{
Augusto Miguel Nascimento Lima ${ }^{(2)}$, Ivo Ribeiro da Silva ${ }^{(3,7)}$, Jose \\ Luis Stape ${ }^{(4)}$, Eduardo Sá Mendonça ${ }^{(5,7)}$, Roberto Ferreira \\ Novais ${ }^{(3,7)}$, Nairam Félix de Barros ${ }^{(3,7)}$, Júlio César Lima Neves ${ }^{(3,7)}$, \\ Keryn Paul $^{(6)}$, Fernanda Schulthais ${ }^{(3)}$, Phill Polglase ${ }^{(6)}$, John \\ Raison $^{(6)}$ \& Emanuelle Mercês Barros Soares ${ }^{(3)}$
}

\begin{abstract}
Soil organic matter (SOM) plays an important role in carbon (C) cycle and soil quality. Considering the complexity of factors that control SOM cycling and the long time it usually takes to observe changes in SOM stocks, modeling constitutes a very important tool to understand SOM cycling in forest soils. The following hypotheses were tested: (i) soil organic carbon (SOC) stocks would be higher after several rotations of eucalyptus than in low-productivity pastures; (ii) SOC values simulated by the Century model would describe the data better than the mean of observations. So, the aims of the current study were: (i) to evaluate the SOM dynamics using the Century model to simulate the changes of $\mathrm{C}$ stocks for two eucalyptus chronosequences in the Rio Doce Valley, Minas Gerais State, Brazil; and (ii) to compare the $\mathrm{C}$ stocks simulated by Century with the $\mathrm{C}$ stocks measured in soils of different Orders and regions of the Rio Doce Valley growing eucalyptus. In Belo Oriente (BO), short-rotation eucalyptus plantations had been cultivated for 4.0; 13.0, 22.0, 32.0 and 34.0 years, at a lower elevation and in a warmer climate, while in Virginópolis (VG), these time periods were 8.0,19.0 and 33.0 years, at a higher elevation and in a milder climate. Soil samples were collected from the 0-20 cm layer to estimate $\mathrm{C}$ stocks. Results indicate that the $\mathrm{C}$ stocks simulated by the Century model decreased after 37 years of poorly managed pastures in areas
\end{abstract}

\footnotetext{
(1) Part of the DS Thesis of the first author presented at the Federal University of Viçosa. Received for publication in March 2009 and approved in March 2011.

(2) Federal University of São Francisco Valley (UNIVASF). 56305-971 Petrolina (PE), Brazil. E-mail: augusto.lima@univasf.edu.br

(3) Soil Science Department, Federal University of Viçosa. 36571-000 Viçosa (MG), Brazil. E-mails: ivosilva@ufv.br; emanuelle.soares@ufv.br

(4) University of São Paulo / North Carolina State University, Raleigh NC, USA. E-mail: jlstape@ncsu.edu

(5) Federal University of Espiríto Santo . 29500-000 Alegre (ES), Brazil.

(6) CSIRO Forestry Research, Canberra, Australia. E-mail: phil.polglase@csiro.au

(7) National Council for Scientific and Technological Development (CNPq) Fellows.
} 
previously covered by native forest in the regions of $\mathrm{BO}$ and VG. The substitution of poorly managed pastures by eucalyptus in the early 1970's led to an average

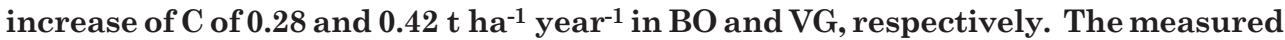
$\mathrm{C}$ stocks under eucalyptus in distinct soil Orders and independent regions with variable edapho-climate conditions were not far from the values estimated by the Century model (root mean square error - RMSE $=20.9$; model efficiency $-\mathrm{EF}=$ 0.29) despite the opposite result obtained with the statistical procedure to test the identity of analytical methods. Only for lower soil C stocks, the model overestimated the $\mathrm{C}$ stock in the 0-20 cm layer. Thus, the Century model is highly promising to detect changes in $\mathrm{C}$ stocks in distinct soil orders under eucalyptus, as well as to indicate the impact of harvest residue management on SOM in future rotations.

Index terms: soil organic matter, land use change, reforestation.

\title{
RESUMO: MODELAGEMDAS MUDANÇAS NOS ESTOQUES DE CARBONO ORGÂNICO DE SOLOS DISTINTOS APÓS QUATRO ROTAÇÕES DO EUCALIPTO NO SUDESTE DO BRASIL COM O MODELO CENTURY
}

\begin{abstract}
A matéria orgânica do solo (MOS) tem importantes funções no ciclo de Ce na qualidade do solo. Considerando a complexidade dos fatores que controlam a ciclagem da MOS e o tempo necessário para que as mudanças sejam nela observadas, a modelagem constitui uma ferramenta muito importante para entender a ciclagem da MOS em solos florestais. As hipóteses do estudo foram: o cultivo do eucalipto por várias rotações resultaria no aumento dos estoques de $C$ do solo, quando comparado a pastagens degradadas; e os valores dos estoques de $C$ do solo simulados pelo modelo Century descreveriam a realidade melhor que a média das observações. Assim, os objetivos do presente estudo foram: avaliar a dinâmica da MOS utilizando o modelo Century para simular as mudanças dos estoques de Cpara duas cronossequências de plantações de eucalipto no Vale do Rio Doce, Minas Gerais, Brasil; e comparar os estoques de C simulados pelo Century com os estoques de $C$ determinados em diferentes ordens de solo em distintas regiões do Vale do Rio Doce cultivadas com eucalipto. Em Belo Oriente (BO), região de menor altitude e temperatura mais elevada, as plantações de eucalipto têm sido cultivadas por 4, 13, 22, 32 e 34 anos, ao passo que em Virginópolis (VG) - região de maior altitude e temperatura mais baixa - os tempos de cultivos com eucalipto foram de 8, 19 e 33 anos. Assim, foram determinados os estoques de $C$ do solo na camada de $0-20 \mathrm{~cm}$. Os resultados indicaram que os estoques de C simulados pelo modelo Century decresceram após 37 anos de pastagem mal manejada em áreas previamente cobertas por mata nativa nas regiões de $B O$ e VG. A substituição da pastagem mal manejada por eucalipto nos anos 70 resultou, em geral, no aumento de 0,28 e 0,42 tha $\mathrm{a}^{-1}$ ano $^{-1}$ de $C$ em $B O$ e VG, respectivamente. Os estoques de $C$ determinados sob eucalipto cultivado em distintas ordens de solo e independentes regiões com variáveis condições edafoclimáticas foram ligeiramente próximos aos valores estimados pelo modelo Century (RMSE = 20,9; eficiência do modelo $-E F=0,29)$, apesar do oposto resultado obtido com o procedimento estatístico para testar a identidade de métodos analíticos. Apenas sob condições de menores estoques de $C$ no solo, o modelo superestimou os estoques de $C$ na camada de 0-20 cm. Assim, o modelo Century tem grande potencial para detectar mudanças nos estoques de $C$ em distintas ordens do solo sob eucalipto em futuras rotações, além de indicar o impacto do manejo do resíduo da colheita na MOS.
\end{abstract}

Termos de indexação: matéria orgânica do solo, mudança de uso da terra, reflorestamento.

\section{INTRODUCTION}

Carbon sequestration in soils constitutes an important option to reduce $\mathrm{CO}_{2}$ emissions to the atmosphere and consequently minimize environmental problems (Izaurralde et al., 2006).
Several studies have shown the potential of soil organic carbon (SOC) to sequester $\mathrm{C}$ in more stable forms (Lal, 2002; Leite et al., 2004; Bayer et al., 2006).

The global SOC contains about four times as much $\mathrm{C}$ as the living pool and three times as much as the atmospheric pool (Lal, 2004). In addition to this role 
as $\mathrm{C}$ storage, $\mathrm{SOM}$ contributes to an improvement in soil quality, supplying nutrients for plants and controlling water and gas fluxes (Woomer et al., 1994; Leite et al., 2004; Gama-Rodrigues et al., 2005). In most cropped systems such as perennial systems (forestry), the SOM pools are closely related to longterm production sustainability due to the beneficial effect on soil quality (Morris et al., 1997; Mendham et al., 2004). In fact, it has recently been found that the SOM content is the most closely correlated soil property with eucalyptus yield in the highly weathered soils in the Rio Doce Valley in Brazil (Menezes, 2005).

Land use changes can either result in $\mathrm{C}$ release or $\mathrm{C}$ sequestration. Consequently, changes in SOC associated with land use have received considerable attention recently due to the need to limit $\mathrm{CO}_{2}$ emissions (Lemma et al., 2006). One of the recommended strategies to mitigate $\mathrm{C}$ emissions to the atmosphere is to increase afforestation of former agricultural and pasture areas, as has occurred with short-rotation eucalyptus in Brazil. However, in a study carried out in Australia, Mendham et al. (2004) observed no difference in the SOC stock when comparing Eucalyptus globulus (11-14 years) with pasture in the $0-10 \mathrm{~cm}$ layer. On the other hand, O'Brien et al. (2003) observed that $E$. regnans (10 $>250$ years) contributed to increase the $\mathrm{C}$ contents in former pasture areas in Australia. Also, Lima et al. $(2006,2008)$ observed an increase in soil C stocks $(0-20 \mathrm{~cm})$ after four eucalyptus rotations in two areas originally under degraded pasture in Minas Gerais, Brazil. However, a recovery in soil $\mathrm{C}$ stocks after substituting a Panicum maximum pasture by eucalyptus was not observed within five years after planting (Balieiro, 2008). Furthermore, Turner \& Lambert (2000) observed a decrease in the $\mathrm{C}$ stock in the $0-10 \mathrm{~cm}$ layer after five years of $E$. grandis cultivation in an area previously under pasture in Australia. These authors estimated that only after 20 years of eucalyptus cultivation the SOM stock would return to the original level. This lack of consistency in experimental results suggests that the direction of SOM changes depends strongly on the previous land use, soil type and the time after land use change.

The complexity of factors that control the SOM dynamics and the lengthy period to observe and quantify SOM changes can be better understood by combining modeling with datasets of experimental areas (Diels et al., 2004; Izaurralde et al., 2006). The Century model simulates SOM decomposition and C, $\mathrm{N}, \mathrm{P}$, and $\mathrm{S}$ fluxes into and among several soil compartments (Parton et al., 1987, 1988, 2004). Century also simulates water fluxes to and from the soil. It has been utilized with success in several temperate ecosystems (Kelly et al., 1997; Del Grosso et al., 2001) and under tropical conditions, including Brazil (Motavalli et al., 1994; Parton et al., 2004; Leite et al., 2004; Ardö \& Olsson, 2004; Cerri et al., 2003, 2004; Chilcott et al., 2007; Galdos et al., 2009;
Tornquist et al., 2009). There is a lack of information for short-rotation eucalyptus in Brazil. Additionally, there are no studies where model simulations for short-rotation eucalyptus have been carried out for agricultural regions with distinct soil and climate conditions. So, the effects of eucalyptus establishment on SOM dynamics are virtually unknown.

The following hypotheses were tested: (i) several eucalyptus rotations increase SOC stocks when compared with former low-productivity pasture; and (ii) SOC values of distinct soils under eucalyptus in contrasting regions in the Rio Doce Valley can be adequately simulated by the Century model.

Therefore, the objectives of this study were: (i) to evaluate the SOM dynamics after pasture substitution by plantations using the Century model for two eucalyptus chronosequences; and (ii) to compare the $\mathrm{C}$ stocks simulated by Century with the $\mathrm{C}$ stocks in different soil Orders in eight regions of the Rio Doce Valley - MG after about 28 years (four rotations) of eucalyptus cultivation.

\section{MATERIALS AND METHODS}

The present study utilized the Century model to simulate C stock dynamics after eucalyptus planting on pasture land. Since there are no long-term records for the calibration of the Century model to evaluate the SOM dynamics in short-rotation eucalyptus plantations, this study evaluated the performance of the model in simulating the pattern of temporal changes in two eucalyptus chronosequences. Soil C stocks for isolated eucalyptus stands located in eight regions with distinct soil Order and climate were also simulated.

\section{The century model}

The Century model is a plant-soil ecosystem model that simulates plant production, soil $\mathrm{C}$ turnover, soil nutrient cycling, temperature and soil water relations (Parton et al., 1987, 1988, 1993). Initially, this model was used to simulate the biomass production and SOM dynamics in the prairie ecosystem of the United States (Parton et al., 1987), and later modified to be used in forest ecosystems (Motavalli et al., 1994; Kirschbaum $\&$ Paul, 2002). However, the application of Century to tropical soils without adequate calibration has been questioned (Gijsman et al., 1996; Leite, 2002). The SOM and nutrient sub-models represent the flow of $\mathrm{C}, \mathrm{N}, \mathrm{P}$ and $\mathrm{S}$ in plant litter and different organic and inorganic soil pools, with mineralization of soil nutrients resulting primarily from the turnover of SOM pools. The plant production sub-model calculates plant production and allocation of nutrients to live aboveground and belowground compartments as a function of climatic factors and available soil 
nutrients. Key variables are monthly precipitation, monthly average minimum and maximum temperatures. Soil texture, litter $\mathrm{N}$ and lignin content and tillage disturbance are also important ratecontrolling factors. Century divides SOM into three compartments: active, slow and passive. The active pool includes soil microbes and microbial products with short turnover time (1-3 months). The slow SOM pool includes resistant material derived from structural plant material and stabilized soil microbial products with turnover times ranging from 10 to 50 years, depending on the climate. The passive pool includes physically and chemically stabilized SOM that is very resistant to decomposition (cycling time from 400 to 4000 years), usually represented by the pool of humic substances. The complete description of the Century model structure and the equations used to describe $\mathrm{C}$ and nutrient fluxes are discussed by Parton et al. (1987, 1988, 1993) and Metherel at al. (1994).

\section{The eucalyptus chronosequences}

The eucalyptus chronosequences studied are located in the regions of Belo Oriente (BO) and Virginopolis (VG). The elevation of the $\mathrm{BO}$ region is $250 \mathrm{~m}$ above sea level (masl), the mean annual temperature $25^{\circ} \mathrm{C}$, and eucalyptus yield (stem without bark) of seven-year-old trees $26 \mathrm{~m}^{3} \mathrm{ha}^{-1}$ year-1; the $^{-1}$ soil is a clayey Yellow Latosol (Oxisol). The elevation of the $\mathrm{VG}$ region is 850 masl, the mean annual temperature $22{ }^{\circ} \mathrm{C}$, and eucalyptus yield of seven-yearold trees $42 \mathrm{~m}^{3} \mathrm{ha}^{-1}$ year $^{-1}$; the soil is a clayey Red Latosol (Oxisol). The distance between these two regions is approximately $100 \mathrm{~km}$, and since the rainfall rate and distribution over the year are very similar, they offer a good opportunity to evaluate the effect of $\mathrm{C}$ addition and different edaphoclimatic conditions (mainly altitude and clay content) on the SOM dynamics after the substitution of poorly managed pastures by short-rotation eucalyptus. The length of the harvesting cycle in all regions is approximately seven years.

In BO, eucalyptus stands have been cultivated for $4.0 ; 13.0,22.0,32.0$ and 34.0 years, while in VG these periods were 8.0, 19.0 and 33.0 years (Table 1 ). In each region, areas under Atlantic forest and pastures near the eucalyptus stands were also selected for sampling. Currently, the total area with eucalyptus in each region covers approximately 30,000 ha. The eucalyptus sites selected for soil sampling are representative of each region; they cover approximately 10 ha and are located in the mid-slope position. Soil samples were collected between tree rows, in the 0-20 cm layer, after digging a pit (depth about $40 \mathrm{~cm}$ ). One pit was opened for each soil use in each soil order in each region. From the same pit undisturbed soil samples were also taken to determine soil bulk density. For this purpose, a field core sampling tool was used to drive a metal cylinder into the middle of the soil layer and a sample of known volume (within the cylinder) was extracted, dried, weighed and then used for soil bulk density calculation. Two cylinders were collected per pit. In the chronosequences of Belo Oriente and Virginópolis separate but similar eucalyptus stands were used as replicates, as described by Lima et al. (2006). However, in the second part of the study, when eight different regions were evaluated, the lack of enough eucalyptus stands with the same age and history of use of the same soil Order (besides being near pasture and native vegetation remnants) forced the use of pseudo-replicates within a single stand. Thus, three pseudo-replicates were randomly assigned to each stand. The pseudo-replicates were esparated by more than $100 \mathrm{~m}$ and consisted of a composite of four randomly collected soil samples, $20 \mathrm{~m}$ apart from each other. Soil sampling was carried out during the rainy season in stands as close as possible to harvest age. The same procedure was used to sample soils in the adjacent native forest and pasture.

In each region, the tropical forest (Atlantic forest) (IBGE, 1993) consisted of trees with an average height of more than $12 \mathrm{~m}$. This forest is predominant in the Rio Doce Valley and covers approximately $30.56 \%$ of the total region (Drumond, 1996). The main tree species found in the native forest are: Newtonia contorta, Pouteria sp., Sloaneae sp., Endlicheria paniculata, Carpotroche brasiliensis, Ocotea odorifera and Sorocea bonplandii, Brosimum. The pastures (mostly Melinis minutiflora) were established in the 1930s after slash-burning the native forest. In that period, the areas under pasture had not been fertilized

Table 1. Soil use, time under short-rotation eucalyptus, soil physical properties and organic carbon in the $0-20 \mathrm{~cm}$ layer of two chronosequences of eucalyptus plantations in the regions of Belo Oriente (BO) and Virginópolis (VG)

\begin{tabular}{|c|c|c|c|c|c|c|}
\hline Soil use & Time & Sand & Silt & Clay & $\begin{array}{c}\text { Bulk } \\
\text { density }\end{array}$ & SOC \\
\hline & years & 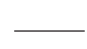 & \multicolumn{2}{|c|}{$\mathrm{g} \mathrm{kg}^{-1}$} & \multirow[t]{2}{*}{$\mathrm{kg} \mathrm{dm}^{-3}$} & $\mathrm{t} \mathrm{ha}^{-1}$ \\
\hline \multicolumn{6}{|c|}{ Belo Oriente } & \\
\hline Native forest & - & 370 & 60 & 570 & 1.09 & $53.00 \pm 2.80$ \\
\hline Pasture & - & 460 & 70 & 470 & 1.37 & $31.54 \pm 3.60$ \\
\hline Eucalypt & 4.0 & 290 & 90 & 620 & 1.22 & $39.20 \pm 2.70$ \\
\hline Eucalypt & 13.0 & 360 & 50 & 590 & 1.14 & $40.40 \pm 2.35$ \\
\hline Eucalypt & 22.0 & 240 & 70 & 690 & 1.15 & $47.63 \pm 2.60$ \\
\hline Eucalypt & 32.0 & 310 & 40 & 650 & 1.40 & $38.77 \pm 4.00$ \\
\hline Eucalypt & 34.0 & 370 & 50 & 580 & 1.41 & $41.55 \pm 0.62$ \\
\hline \multicolumn{7}{|c|}{ Virginópolis } \\
\hline Native forest & . & 320 & 40 & 640 & 0.87 & $69.20 \pm 2.65$ \\
\hline Pasture & & 300 & 50 & 650 & 0.91 & $54.99 \pm 1.70$ \\
\hline Eucalypt & 8.0 & 450 & 30 & 520 & 1.13 & $49.00 \pm 2.40$ \\
\hline Eucalypt & 19.0 & 240 & 70 & 690 & 0.96 & $66.00 \pm 3.20$ \\
\hline Eucalypt & 33.0 & 250 & 50 & 700 & 0.93 & $69.72 \pm 3.30$ \\
\hline
\end{tabular}

SOC: Soil organic carbon, \pm Standard deviations. 
but were overgrazed. Consequently, there was interrill erosion due to the practice of annual burning during the dry winter. This exposed the soil surface directly to erosion by rain impact, resulting in pasture degradation over the years. In 1969, the eucalyptus plantation replaced the pasture. The first eucalyptus stands were planted manually after burning the pasture. After seven years (harvesting cycle) the trees were harvested (clear-cut) and removed from the area. Then, the tree residues were burnt to clear the area for the second cycle. Until the third eucalyptus harvesting cycle, the harvest operation involved the cutting and removal of the wood from the area and burning the tree residues. Burning the forest residues was gradually discontinued from the fourth harvesting cycle. In all rotations, no bark was returned to the site after off-site debarking. With the exception of tree harvest, all management practices were carried out manually because of the steep relief of the sites.

\section{The eight regions in the Rio Doce Valley}

The eucalyptus plantations were located in the following eight regions of the Rio Doce Valleys: 1. Belo Oriente (BO), 2. Nova Era (NE), 3. Santa Bárbara (SB), 4. Virginópolis (VG), 5. Sabinópolis (SAB), 6. Correntinho (COR), 7. Ipaba (IP) and 8. Cocais (CO) (Figure 1). The climate (Köppen classification) of BO and IP is Aw (humid subtropical), and Cwa (tropical wet-dry) in the other regions (Nimer, 1989) (Table 2).

Sites belonging to the different predominant soil Orders in the eight distinct regions were selected that had been under short-rotation eucalyptus plantations for 28 years (four rotations) (Table 3). In addition, areas under native forest (Atlantic forest) near the eucalyptus plantation were also chosen as reference.

Unfortunately, the extensive forest clearing for ranching in the past century left only few forest remnants in the region. Sampling the same soil order

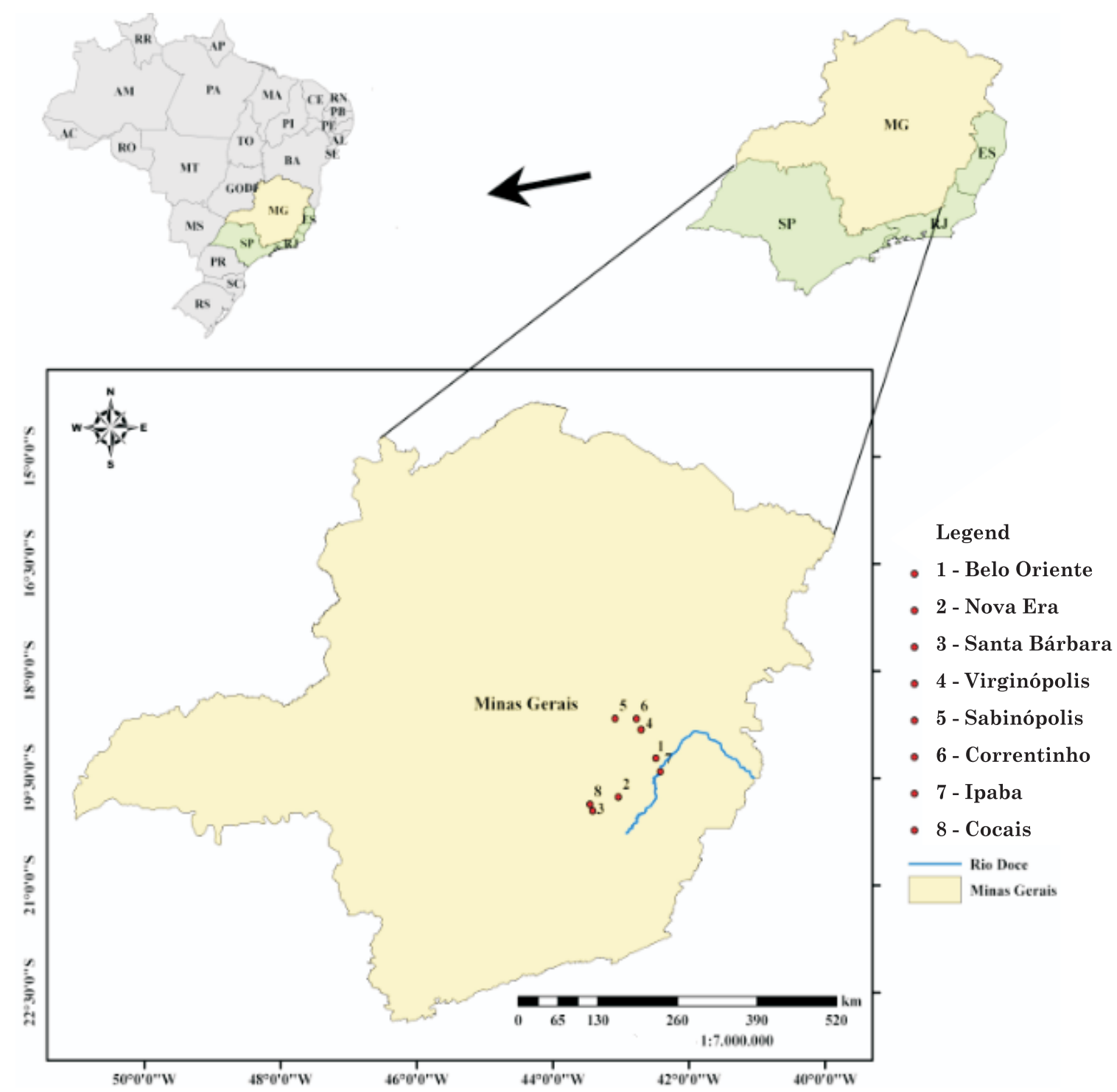

Figure 1. Geographic localization of the eight regions studied in the Rio Doce Valley, Minas Gerais, Brazil. 
Table 2. Climate characteristics and elevation of the studied areas (sites)

\begin{tabular}{lrrrrr}
\hline $\begin{array}{c}\text { Climate } \\
\text { characteristics }\end{array}$ & PPT & $\overline{\mathbf{T}}_{\text {annual }}$ & $\overline{\mathbf{T}}_{\text {max }}$ & $\overline{\mathbf{T}}_{\text {min }}$ & Altitude \\
& $\mathrm{mm}$ & & ${ }^{\circ} \mathrm{C}$ & & masl \\
Belo Oriente & 1,163 & 25.0 & 31.2 & 18.9 & 250 \\
Nova Era & 1,444 & 18.5 & 21.9 & 15.6 & 837 \\
Santa Bárbara & 1,450 & 22.3 & 27.2 & 17.3 & 838 \\
Virginópolis & 1,153 & 22.0 & 22.8 & 15.3 & 850 \\
Sabinópolis & 1,183 & 21.7 & 26.7 & 15.9 & 899 \\
Correntinho & 1,342 & 20.0 & 24.3 & 16.6 & 843 \\
Ipaba & 1,204 & 24.8 & 31.2 & 18.9 & 276 \\
Cocais & 1,281 & 20.7 & 25.2 & 15.1 & 1016
\end{tabular}

PPT: Average annual precipitation, $\overline{\mathrm{T}}_{\text {annual }}$ : Average annual temperature, $\overline{\mathrm{T}}_{\max }$ : Average maximum temperature, $\overline{\mathrm{T}}_{\text {min }}$ : Average minimum temperature under all uses was therefore impossible. The management practices since the substitution of the native forest by pastures, and more recently by eucalyptus, were similar to those described above.

\section{Soil analysis}

Soil samples were air-dried and passed through a $2 \mathrm{~mm}$ sieve. Sub-samples were taken for texture analysis (Tables 1 and 3). Soil sub-samples were also ground in an agate mortar to pass a 100 mesh (0.149 $\mathrm{mm}$ ) sieve for organic $\mathrm{C}$ determination by a wet chemical procedure (Yeomans \& Bremner, 1988). Despite a close correlation between the wet-chemical procedure (Walkley-Black) and reference dry combustion methods, the wet-chemical procedure is limited due to a partial $\mathrm{C}$ recovery, which usually leads to an underestimation of the $\mathrm{C}$ content in the

Table 3. Soil order, use, texture, bulk density soil organic carbon (0-20 cm ) of soils under native forest and eucalyptus and eucalyptus productivity (mean annual increment) for the eight regions in study

\begin{tabular}{|c|c|c|c|c|c|c|c|}
\hline Soil order ${ }^{(1)}$ & Soil use & Sand & Silt & Clay & BD & SOC & $\begin{array}{c}\text { Eucal. stem } \\
\text { produc. }^{(1)}\end{array}$ \\
\hline & & \multicolumn{3}{|c|}{$\mathrm{g} \mathrm{kg}^{-1}$} & $\mathrm{~kg} \mathrm{dm} \mathrm{m}^{-3}$ & $\mathrm{t} \mathrm{ha}^{-1}$ & $\mathrm{Mgha}^{-1} \mathrm{yr}^{-1} \mathrm{C}$ \\
\hline & & \multicolumn{3}{|c|}{ Belo Oriente (BO) } & & & \\
\hline Oxisol & Native forest & 280 & 50 & 670 & 1.14 & $51.60 \pm 4.10$ & \\
\hline Oxisol & Eucalypt & 250 & 60 & 690 & 1.41 & $44.60 \pm 1.65$ & 7.1 \\
\hline Inceptisol & Eucalypt & 280 & 70 & 650 & 1.42 & $45.80 \pm 2.65$ & 6.8 \\
\hline \multirow[t]{2}{*}{ Entisol } & Eucalypt & 480 & 190 & 330 & 1.46 & $34.10 \pm 6.60$ & 7.3 \\
\hline & & \multicolumn{3}{|c|}{ Nova Era (NE) } & & & \\
\hline Inceptisol & Native forest & 420 & 90 & 490 & 1.10 & $69.40 \pm 2.05$ & \\
\hline Oxisol & Eucalypt & 530 & 30 & 440 & 1.27 & $53.20 \pm 2.35$ & 8.6 \\
\hline \multirow[t]{2}{*}{ Inceptisol } & Eucalypt & 370 & 80 & 550 & 1.17 & $48.90 \pm 6.10$ & 6.9 \\
\hline & & \multicolumn{3}{|c|}{ Santa Bárbara (SB) } & & & \\
\hline Oxisol & Native forest & 420 & 90 & 490 & 1.24 & $50.80 \pm 0.80$ & \\
\hline Oxisol & Eucalypt & 390 & 110 & 500 & 1.26 & $46.80 \pm 2.70$ & 8.6 \\
\hline \multirow[t]{2}{*}{ Inceptisol } & Eucalypt & 430 & 100 & 470 & 1.45 & $48.40 \pm 0.65$ & 7.5 \\
\hline & & \multicolumn{3}{|c|}{ Virginópolis (VG) } & & & \\
\hline Inceptisol & Native forest & 520 & 120 & 360 & 1.22 & $50.00 \pm 3.15$ & \\
\hline Oxisol & Eucalypt & 220 & 60 & 720 & 1.07 & $74.70 \pm 3.70$ & 10.9 \\
\hline \multirow[t]{2}{*}{ Inceptisol } & Eucalypt & 370 & 100 & 530 & 0.85 & $68.50 \pm 1.35$ & 8.8 \\
\hline & & \multicolumn{3}{|c|}{ Sabinópolis (SAB) } & & & \\
\hline Oxisol & Native forest & 390 & 60 & 550 & 1.15 & $71.30 \pm 2.60$ & \\
\hline Oxisol & Eucalypt & 340 & 50 & 610 & 1.26 & $55.60 \pm 4.65$ & 7.7 \\
\hline \multirow[t]{2}{*}{ Inceptisol } & Eucalypt & 220 & 100 & 680 & 1.22 & $55.00 \pm 1.45$ & 8.3 \\
\hline & & \multicolumn{3}{|c|}{ Correntinho (COR) } & & & \\
\hline Oxisol & Native forest & 60 & 130 & 810 & 0.84 & $70.10 \pm 0.00$ & \\
\hline Oxisol & Eucalypt & 60 & 100 & 840 & 0.97 & $59.30 \pm 2.70$ & 8.8 \\
\hline \multirow[t]{2}{*}{ Inceptisol } & Eucalypt & 220 & 100 & 680 & 1.22 & $51.40 \pm 2.50$ & 8.8 \\
\hline & & \multicolumn{3}{|c|}{ Ipaba (IP) } & & & \\
\hline Inceptisol & Native forest & 320 & 80 & 600 & 1.26 & $83.50 \pm 3.10$ & \\
\hline Oxisol & Eucalypt & 310 & 60 & 630 & 1.55 & $43.70 \pm 3.35$ & 7.3 \\
\hline \multirow[t]{2}{*}{ Entisol } & Eucalypt & 640 & 120 & 240 & 1.65 & $28.70 \pm 1.30$ & 7.3 \\
\hline & & \multicolumn{3}{|c|}{ Cocais (CO) } & & & \\
\hline Inceptisol & Native forest & 500 & 100 & 400 & 1.07 & $52.40 \pm 3.75$ & \\
\hline Oxisol & Eucalypt & 340 & 50 & 610 & 1.13 & $82.70 \pm 4.55$ & 8.6 \\
\hline Inceptisol & Eucalypt & 440 & 110 & 450 & 1.18 & $53.60 \pm 7.05$ & 9.6 \\
\hline
\end{tabular}

${ }^{(1)}$ At seven year-old, SOC: Soil organic carbon, \pm Standard deviations. BD: Soil bulk density. 
sample (Dieckow et al., 2007), possibly because of incomplete oxidation of the total organic $\mathrm{C}$ in the Walkley-Black procedure. These authors also found that the methods of $\mathrm{C}$ determination did not affect the interpretation of the effects of management systems on soil $\mathrm{C}$ stocks, indicating that both methodological approaches provide comparable conclusions for soil organic matter studies. The $\mathrm{C}$ stock under each land use was calculated by multiplying the SOC concentration by soil mass to a depth of $20 \mathrm{~cm}$ in the native forest. SOC stock on a fixed depth basis can be affected if corrections are not applied because the bulk density of managed soils is usually greater than of undisturbed sites (Ellert \& Bettany, 1995). We are aware that the use of pseudoreplications is a limitation of the present study, as in many other paired-site studies (Vesterdal et al., 2002; O'Brien et al., 2003; Chen et al., 2004, Lima et al., 2006). Considering that each stand of a given site was separated by at least several kilometers from other eucalyptus stands, we are sure that randomness and independence were ensured, as pointed out in a previous study (Lima et al., 2006).

\section{Calibration of the century model}

The Century model 4.0 was parameterized and calibrated for the BO chronosequence where most information was available, especially for data on quality of eucalyptus biomass material. The monthly climate input variables were obtained from climatologic stations located near the study sites for the period 1985-2005 (Table 2). Other input variables such as soil texture (sand, silt and clay), soil density and soil $\mathrm{C}$ stocks were measured at each site (Table 1 and Figure 2). The productivity and quality $(\mathrm{C} / \mathrm{N}$, lignin/ $\mathrm{N}$, etc) data of biomass material of eucalyptus were obtained from the literature, and whenever possible from studies with the same local conditions (Leite, 1996; Ladeira, 1999; Faria 2000) (Table 4). Once adequately calibrated for the BO region, the performance of the Century model to simulate SOM dynamics for the other eucalyptus chronosequence in the VG region was evaluated, as well as for the other eight independent regions (see below).

The option Luquillo trees (from TREE.100 parameter file in the Century model) was used for the native forest, where the parameters PRDX (maximum

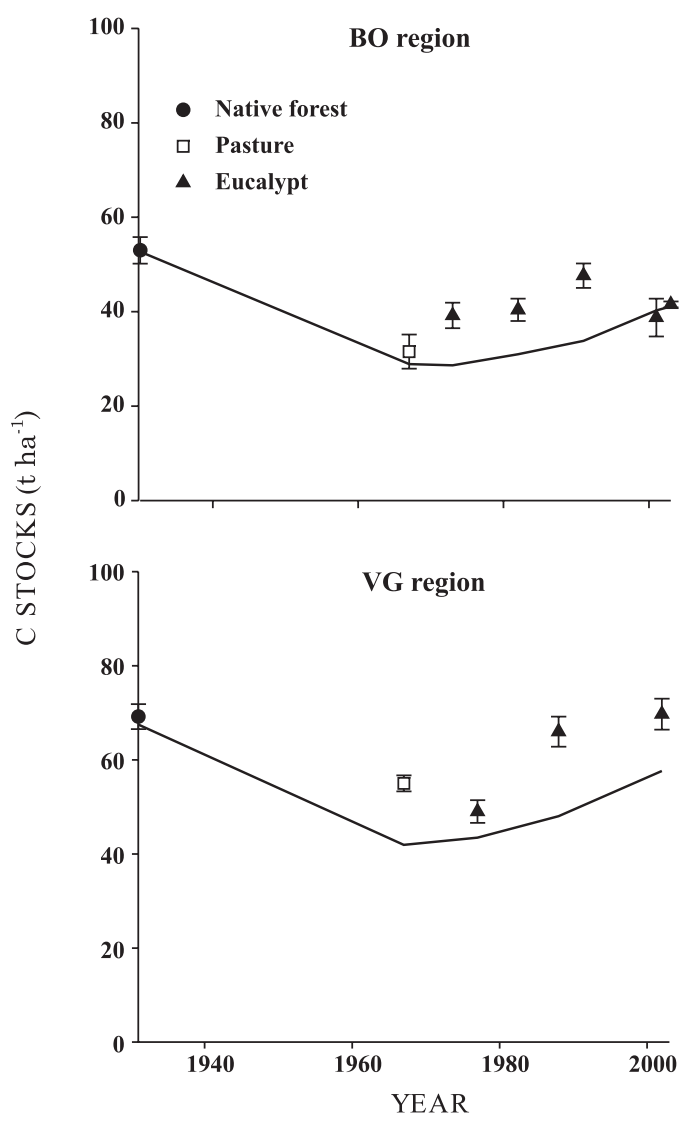

Figure 2. Observed (symbols) and simulated (solid line) SOC stocks by Century for the 0-20 cm soil layer of eucalyptus chronosequences in the regions of Belo Oriente (BO) and Virginópolis (VG).

forest production excluding respiration) were modified to tune the model to obtain the desired forest production. For the pasture, the option grass warmseason crop species (G2, from CROP.100 parameter file) was used, where the potential aboveground monthly production for crops - PRDX (1) was adapted to attain the desired crop production. The equilibrium simulation of soil $\mathrm{C}$ stock using the native forest as reference was performed for a period of 7,000 years before starting the simulations of soil use changes. The Atlantic forest productivity simulated at equilibrium was $115.7 \mathrm{t} \mathrm{ha}^{-1}$, while the actual measured productivity was $112.0 \mathrm{t} \mathrm{ha}^{-1}$ (Drumond,

Table 4. General inputs for eucalyptus components used for calibration of the Century model

\begin{tabular}{|c|c|c|c|c|c|}
\hline Input & Leaf & Fine root & Fine branch & Trunk & Coarse root \\
\hline $\mathrm{C} / \mathrm{N}$ & $20^{(1)}$ & $182^{(2)}$ & $160^{(3)}$ & $400^{(1)}$ & $178^{(3)}$ \\
\hline $\mathrm{C} / \mathrm{P}$ & $400^{(1)}$ & $267^{(2)}$ & $1000^{(1)}$ & $8000^{(1)}$ & $102^{(2)}$ \\
\hline Lignin (\%) & 41.1 & 28.2 & 21.7 & $22.1^{(4)}$ & 28.2 \\
\hline Assumed $\mathrm{C}$ allocation (\%) & 1.05 & 2.7 & 2.7 & 84.8 & 8.8 \\
\hline
\end{tabular}

(1) Leite (1996). ${ }^{(2)}$ Ladeira (1999). ${ }^{(3)}$ Faria (2000). ${ }^{(4)}$ Paul \& Polglase (2004). The same lignin percentage was assumed for fine and coarse roots. The $\mathrm{C}$ allocation of fine roots refers to the sum of $\mathrm{C}$ allocation to the medium and fine roots. 
1996). The equilibrium simulation values were used as input data to start simulating the impact of land use changes on SOM. It should be noted, however, that although a steady-state condition was assumed for the native forest biomass and soil $\mathrm{C}$ (as in virtually all studies published on $\mathrm{C}$ modeling), a more recent study in the Amazon region indicated that the forest biomass has been increasing over the years (Phillips et al., 2008) and may have effects on soil C too. Future studies would be necessary if this is the case in the Atlantic forest region.

\section{Evaluation of the previously calibrated century model}

The performance of Century model calibrated for the $\mathrm{BO}$ region was evaluated/ validated by simulating SOM dynamics in the VG chronosequence. Thereafter, independent simulations of SOM stocks of different soils under eucalyptus in the eight study regions were run. Local conditions included climate data (temperature, precipitation), soil texture, soil C stocks, soil density, soil use and management practices (use history, burning, harvest type). Soil C stocks were estimated by the Century model 4.0, and the estimated and measured values were compared for each region.

The relative difference (\%) between simulated and measured values was computed for each soil order and region in the study. After calibration, the quality of the Century model prediction of the SOC stocks was determined by calculating the model efficiency (EF), a statistic analogous to $\mathrm{R}^{2}$, as defined by Soares et al. (1995):

$$
E F=1-\left(\frac{\sum(y i-\hat{y} i)^{2}}{\sum(y i-\bar{y})^{2}}\right)
$$

where y $i$ are the measured/observed values, $\hat{y} i$ are the predicted values, $\bar{y}$ is the mean of the measured data. The EF value may be negative or positive with a maximum value of 1 . A negative value indicates that the simulated values describe the trend in the measured data less well than the mean of the observations. A positive value indicates that the simulated values describe the data much better than the mean of observations, while a value of 1 indicates a perfect fit. The coefficient of determination, also denoted as $\mathrm{R}^{2}$, provides auxiliary information to the results of regression variance analysis to verify if the proposed model is adequate or not to describe the phenomenon, as defined:

$$
R^{2}=\left(\frac{S Q \operatorname{Re} g}{\text { SQTotal }}\right)
$$

where: SQReg is the regression square sum and SQTotal is the total square sum. The $\mathrm{R}^{2}$ varies between 0 and 1 . Values closer to 1 indicate that the proposed model is adequate to describe the phenomenon. All results were also compared by the root mean square error (RMSE) (Cerri et al., 2007;
Kamoni et al., 2007). Further methodological details may be found in Smith et al. (1997).

$$
R M S E=\frac{100}{\bar{y}} \sqrt{\left(\frac{\sum_{i=1}^{n}(\hat{y} i-y i)^{2}}{n}\right)}
$$

where $\hat{y} i$ are the predicted values, $\hat{y}$ are the mean measured data, y $i$ are measured values, and $\mathrm{n}$ is the number of paired values. A statistical procedure to test the identity of analytical methods $(\alpha=0.05)$ was also applied, according to Leite \& Oliveira (2002). The proposed procedure results from the combination of the F test modified by Graybill (1976), t test for the medium error, and analysis of the linear correlation coefficient to check if the simulated values by the Century model differ from the measured values. Based on this information, a decision rule was proposed to test the hypothesis of identity between two analytical methods or any two vectors, that is, groups of quantitative data.

\section{RESULTS}

\section{Measured SOC stocks \\ The $\mathrm{BO}$ region}

Under equilibrium condition, the SOC stock for the native forest was $53.0 \mathrm{t} \mathrm{ha}^{-1}$ (Figure 2). As expected for a steady-state system, the SOC stock of the native forest was stable until 1931, but the establishment of pasture resulted in a reduction of $40.5 \%$ (31.5 $\left.\mathrm{t} \mathrm{ha}^{-1}\right)$ of the SOC stock. On the other hand, four rotations of eucalyptus plantation in soils previously under poorly managed pasture favored a recovery of the SOC stock. After 34 years of eucalyptus cultivation the observed SOC stock was $41.5 \mathrm{t} \mathrm{ha}^{-1}$ (31.7\% greater than in the former pasture soil). The results indicated substantial variations in the SOC stock when the native forest was replaced by pasture, which in turn was substituted by short-rotation eucalyptus resulting in another sequence of variations in the SOC stock.

\section{The VG region}

The observed SOC stock for the soil under native forest was $69.2 \mathrm{t} \mathrm{ha}^{-1}$ in the VG region (Figure 2). For pasture, SOC stock of $55.0 \mathrm{t} \mathrm{ha}^{-1}$ was observed, indicating a reduction of $20.5 \%$ in SOC when compared with that under native forest. After four rotations, eucalyptus planted on pasture soil led to an increase of $26.8 \%\left(69.7 \mathrm{t} \mathrm{ha}^{-1}\right)$ in the SOC stock.

\section{Simulated SOC stocks}

\section{The $\mathrm{BO}$ region}

In the $\mathrm{BO}$ region, the $\mathrm{SOC}$ stock simulated for the native forest was $52.7 \mathrm{t} \mathrm{ha}^{-1}$, while 37 years of pasture cultivation after forest removal resulted in a reduction 
of $45.2 \%$ (28.9 t ha-1) (Figure 2). Contrastingly, four eucalyptus rotations resulted in a SOC stock of $41.1 \mathrm{t} \mathrm{ha}^{-1}$, i.e., an increase of $42.2 \%$ in SOC stock when compared to the pasture soil.

\section{The VG region}

After calibration for the $\mathrm{BO}$ region, independent simulations with the Century model estimated a SOC stock of $67.5 \mathrm{t} \mathrm{ha}^{-1}$ for the native forest in the VG region (Figure 2). A $37.9 \%$ lower SOC stock $\left(41.9 \mathrm{t} \mathrm{ha}^{-1}\right)$ was estimated for soil under pasture than under the previous vegetation (native forest). The Century model simulated 33 years of eucalyptus plantation which resulted in a $37.5 \%$ increase of the SOC stock over the previous pasture use.

Observed and simulated SOC stocks for different soil Orders and regions

In the $\mathrm{BO}$ region, the simulated SOC stock for the Oxisol under native forest was $11.6 \%$ higher than the measured SOC stock, while the difference was only $-3.5 \%$ in the region of Santa Barbara (SB) (Figure 3). In the regions of $\mathrm{BO}$ and $\mathrm{SB}$, the simulated SOC stocks for the Oxisol under eucalyptus differed 8.2 and $-8.2 \%$ from the observed values, respectively. For the BO region, the simulated SOC stocks for the
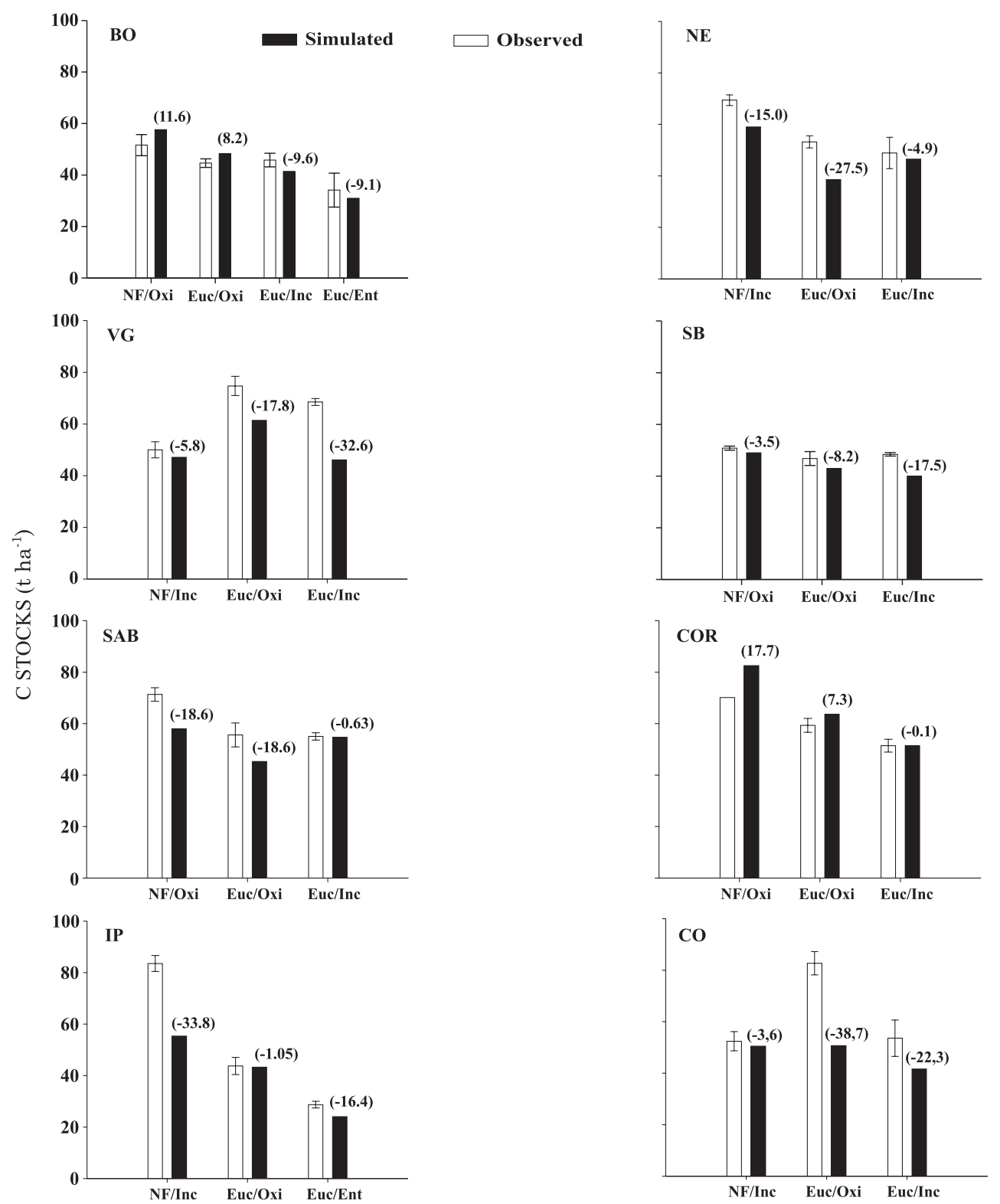

USE/SOIL ORDER

Figure 3. Observed and simulated SOC stocks of the 0-20 cm layer of soils of the regions of Belo Oriente (BO), Nova Era (NE), Santa Bárbara (SB), Virginópolis (VG), Sabinópolis (SAB), Correntinho (COR), Ipaba (IP) and Cocais (CO). The values in brackets refer to the difference (\%) between simulated and observed values. NF - Native forest, Euc - Eucalyptus, Oxi - Oxisol, Inc - Inceptisol, Ent - Entisol. 
Inceptisol and Entisol under eucalyptus differed -9.6 and $-9.1 \%$ from the measured values, respectively. In the SB region, the simulated SOC stock for the Inceptisol under eucalyptus was $17.5 \%$ lower than the measured SOC stock.

For the Nova Era (NE) region, the simulated SOC stock for the Inceptisol under native forest was $15.0 \%$ lower than the measured values. Conversely, in VG the difference was only $-5.8 \%$. In NE and VG, the SOC stocks simulated for the Oxisols under eucalyptus were $27.5 \%$ and $17.8 \%$ lower than the observed SOC stocks, respectively. In NE, the simulated SOC stock differed only $-4.9 \%$ from the observed SOC stock for the Inceptisol under eucalyptus, while for VG the difference was $-32.6 \%$.

For the regions of Sabinópolis (SAB) and Correntinho (COR), the estimated SOC stocks for the Oxisol under native forest differed by $-18.6 \%$ and $+17.7 \%$ from the observed SOC stocks, respectively. For the Oxisol under eucalyptus, the difference was $18.6 \%$ in SAB and $+7.3 \%$ in COR. In the Inceptisol under eucalyptus, the estimated SOC stock was only $0.6 \%$ lower than the observed SOC stock in SAB and only $0.1 \%$ less than the observed values in COR.

In the Ipaba (IP) region, the estimated SOC stock for the Inceptisol under native forest was $33.8 \%$ lower than the observed SOC stock, while the difference was only $-3.6 \%$ in Cocais (CO). For the Oxisol under eucalyptus, the difference of the simulated SOC stock in comparison to the observed values was $-1.05 \%$ in IP and $-38.7 \%$ in CO. In the IP region, the estimated SOC stock by Century was $16.4 \%$ smaller than the observed SOC stock for the Entisol under eucalyptus. However, for the Inceptisol under eucalyptus in CO the difference was $-22.3 \%$.

\section{DISCUSSION}

The efficiency of a model can be assessed by calculating the root mean square error (RMSE) (Smith et al., 1997; Cerri et al., 2007). The RMSE value of $20.9 \%$ found in the present study indicates that the values simulated by the Century model were, in general, close to the measured values (Figure 4). This RMSE value is comparable to (or in some cases greater than) reported by Cerri et al. (2007), who evaluated the performance of the Century model in the simulation of 11 chronosequences of land use changes in the Brazilian Amazon and found RMSE values of around $20 \%$, showing accurate results and supporting the idea that the utilization of Century is a good alternative to study the SOM dynamics under different edapho-climatic conditions and soil uses (Diels et al., 2004; Parton et al., 2004; Izaurralde et al., 2006). The error in simulations of the different models can be verified by the RMSE value; the lower the RMSE value, the more precise the simulation (Smith et al., 1996). In view of the limitations of using chronosequences compared to data derived from welldesigned long-term experiments, this degree of agreement between soil $\mathrm{C}$ measurements and modeled values is considered satisfactory (Cerri et al., 2007). Also, the coincidence between measured and simulated values by the Century model was verified by calculating the model efficiency (EF), according to Soares et al. (1995). The model efficiency was positive $(\mathrm{EF}=0.29)$, in other words, the Century simulations are somewhat better than the mean of the observations, despite the fact that in soils with lower $\mathrm{C}$ stocks the model over-estimated the $\mathrm{C}$ stocks in the 0-20 cm layer (Figure 4). In a study evaluating C and $\mathrm{N}$ stocks in soils under different uses and managements in Minas Gerais, Wendling (2007) showed that the Century model simulated the soil C and $\mathrm{N}$ stocks satisfactorily, which was supported by the similarity between simulated and measured stocks. According to the statistical procedure suggested by Leite \& Oliveira (2002), in general, the values simulated by Century differ from the measured values (significant $F$ test, $\alpha=0.05$ ), based on which it was concluded that, simultaneously, $\beta_{0}$ and $\beta_{1}$ are different from 0 and 1 , respectively (despite $\beta_{1}=1$ by $\mathrm{t}$ test, and slope of the equation is equal to 1 ). Additionally, the t test for the mean error $(\bar{e})$ indicates that the differences between the simulated and measured values are caused by random factors. This test is very conservative because a series of statistical restrictions must be respected. Although the linear correlation coefficient between simulated and measured values was relatively high $(r=0.75)$, the use of this coefficient, separately, is not enough to decide about the identity of two methods (simulated and observed values in the present case) due to the possibility that the intercept and the regression coefficient can be quite different from 0 and 1 , respectively (Leite \& Oliveira, 2002).

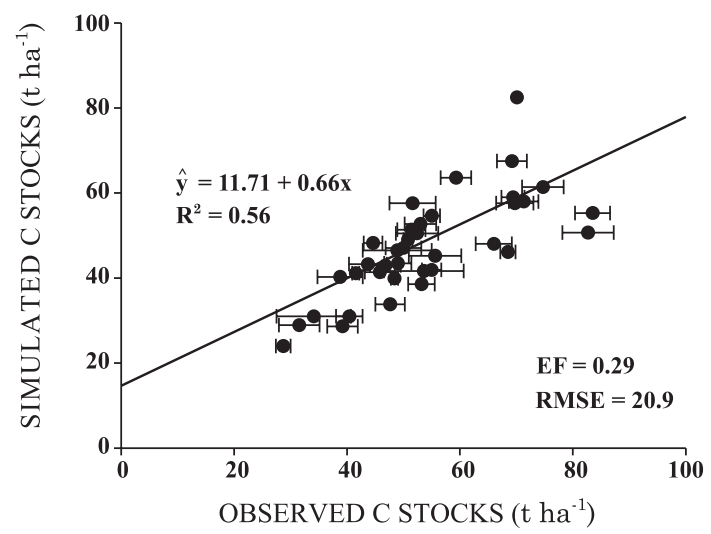

Figure 4. Relationship between the observed and simulated SOC stocks by the Century model for all regions under study. $\mathrm{EF}=$ Model efficiency, RMSE $=$ root mean square error . 
The Century model was parameterized and calibrated to simulate the equilibrium of SOC stocks for the $\mathrm{BO}$ region. Under equilibrium conditions (in BO ), the simulated SOC stock in the native forest was very similar to the observed values, with a difference of only $-0.57 \%$. Leite et al. (2004) and Cerri et al. (2004) also found such a close agreement between the observed and Century- simulated TOC stocks for native forests in Brazil.

Soil use changes result in great regional and local impacts on the $\mathrm{C}$ cycle. The observed and simulated SOC stocks showed a reduction after substitution of native forest by pasture in BO and VG (Figure 2). This decrease can be attributed to the poor management of the pasture, extensive grazing with low inputs and annual burning combined with soil erosion on a steep relief, resulting in high $\mathrm{CO}_{2}$ emissions to the atmosphere. Utilizing the Century model, Polyakov \& Lal (2004) observed that erosion plays a predominant role in SOM loss and $\mathrm{CO}_{2}$ emission. The importance of adequate pasture management was evidenced in a study where simulations of SOC changes in 11 land use chronosequences of the Brazilian Amazon predicted with the RothC and Century models suggested that forest clearance and conversion to well-managed pastures would cause an initial decline in soil $\mathrm{C}$ stock (0-20 cm depth), followed by a slow recovery to levels that could even exceed those under native forest in the majority of cases (Cerri et al., 2007).

The establishment of the eucalyptus plantation in $\mathrm{BO}$ and VG resulted in an increase of the SOC stock in comparison to the pasture (Figure 2). In the BO region the increment was $0.28 \mathrm{t} \mathrm{ha}^{-1}$ year $^{-1}$ of $\mathrm{C}$, while for the VG region it was $0.42 \mathrm{t} \mathrm{ha}^{-1}$ year $^{-1} \mathrm{C}$. Successive eucalyptus rotations with average

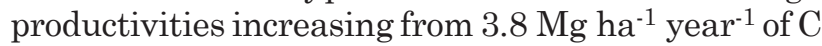
in the $60 \mathrm{~s}$ to $8.8 \mathrm{Mg} \mathrm{ha}^{-1}$ year-1 $^{-1} \mathrm{C}$ in current years (Barros \& Comerford, 2002) contributed substantially to higher depositions of organic residues and, consequently, increases in SOM. In addition, the adoption of minimum tillage without biomass burning and reduced erosion during the establishment of the eucalyptus plantation surely contributed to these gains. In a recent review, the mean rate of $\mathrm{C}$ sequestration in the $0-20 \mathrm{~cm}$ layer of no-tillage soils located in the subtropical Southern region of Brazil was estimated to be $0.48 \mathrm{t} \mathrm{ha}^{-1}$ year $^{-1}$, which is higher than the $0.35 \mathrm{t} \mathrm{ha}^{-1}$ year-1 observed for the tropical region of Brazil (Bayer et al., 2006). Thus, for the eucalyptus rotations the rates of $\mathrm{C}$ sequestration in BO paralleled those found for soils cultivated with annual crops in the warmer tropical region of Brazil, whereas the potential for $\mathrm{C}$ sequestration in $\mathrm{VG}$ is somewhat similar to that found for the milder subtropical region of Brazil.

These results highlight the great potential of eucalyptus to increase $\mathrm{C}$ sequestration in former pasture soils, as also observed for yet another soil
Order in a distinct region in Brazil (Balieiro et al., 2008). The substitution of degraded pasture associated with frequent use of fire and overgrazing by eucalyptus cultivation in a minimum tillage system contributed to increase $\mathrm{C}$ sequestration in soils. It is not known, however, whether the $\mathrm{C}$ build-up will continue. The net change will probably depend on previous land use (Silver et al., 2000). In a study conducted in an area under regenerated native forest ( $E$. regnans) after wild fire in Australia, O'Brien et al. (2003) observed that $E$. regnans cultivation (10 to $>250$ years) resulted in increases of the SOC content, but the decrease in soil density permitted no gains in the SOC stocks. Evaluating soil C sequestration under different exotic species in the Southwestern highlands of Ethiopia, Lemma et al. (2006) observed that 20 years after afforestation with $E$. grandis after 35 consecutive years of pasture and 20 years of agriculture the SOC returned to nearly the level of the native forest. The data reviewed by Guo \& Gifford (2002) indicated that planting conifers in soil previously under pasture decreased the SOC by $12 \%$, while plantations of broadleaf species (Eucalyptus and Populus) resulted in no changes in SOC. Turner \& Lambert (2000) observed a decrease in SOC in the 0-10 cm layer in soil after five years of E. grandis in an area previously under pasture in Australia. These authors estimated that the return of $\mathrm{C}$ to the initial level would occur after approximately 20 years of eucalyptus cultivation. High residue addition and $\mathrm{C}$ accretion by annual crops in more superficial soil layers may lead to saturation of some SOM sorption surfaces, especially in the clay fraction (Dieckow et al., 2005), while C deposition deeper in the soil profile by eucalyptus roots may circumvent this limitation and extend the period of net $\mathrm{C}$ sequestration. In a study carried out in a Brazilian eucalyptus plantation to evaluate the fine root production and turnover under contrasting $\mathrm{N}$ fertilization systems, Jourdan et al. (2008) observed 1.67 and $1.61 \mathrm{t} \mathrm{ha}^{-1}$ of fine root biomass (diameter $<1$ $\mathrm{mm}$ ) down to a depth of $3 \mathrm{~m}$ one year after planting, in a control (no nitrogen) and $\mathrm{N}$-fertilized area, respectively. Evaluating C accumulation under zerotillage and conventional tillage in subtropical agriculture (15-26 years) in Southern Brazil, Boddey et al. (2010) observed annual soil $\mathrm{C}$ accumulation rates of 0.04 to $0.88 \mathrm{Mg} \mathrm{ha}{ }^{-1}$ under no-tillage to a depth of $30 \mathrm{~cm}$ in comparison to conventional tillage. These authors also observed increases in soil $\mathrm{C}$ accumulation (0.48-1.53 Mg ha-1 year $\left.{ }^{-1}\right)$ when the $100 \mathrm{~cm}$ soil layer was considered.

The sensibility of the Century model to variations in soil use under different soil and climate conditions, as presented in this study, illustrates the great potential of this model to detect SOM changes in the long term. It can be utilized as a tool for simulating possible management scenarios and be a support in the implementation of practices favoring the increase of soil C. The values of SOC stocks simulated by the Century model for native forest, pasture and 
eucalyptus in the VG chronosequence were higher than of SOC stocks in the BO chronosequence (Figure 2). The higher clay content plus lower average annual temperature (Tables 1 and 2) in the VG region may have had an influence. On clay particles, $\mathrm{C}$ is stabilized mainly by association with soil minerals, resulting in protection against biological degradation (Schulten \& Leinweber, 2000; Kaiser et al., 2002; Dalmolin et al., 2006). In soils under eucalyptus, pasture and native forest at 10 Australian sites, with SOC varying from 19 to $83 \mathrm{~g} \mathrm{~kg}^{-1}(0-10 \mathrm{~cm})$, Mendham et al. (2002) observed that in general, SOC contents were higher and $\mathrm{C}$ mineralization rates lower in finer texture soils. Studying Ferralsol profiles along a climosequence in Southern Brazil, Dalmolin et al. (2006) observed that the organic matter content increased from the lowest to the highest sites (440950 masl) as result of an increase in rainfall and a decrease in temperature. This influence was more pronounced in the clayey Ferralsols, suggesting that organic matter accumulation was enhanced by SOMmineral interactions. In addition, the eucalyptus yield in the VG region $\left(10.5 \mathrm{Mg}^{-1} \mathrm{yr}^{-1} \mathrm{C}\right)$ was higher than in the $\mathrm{BO}$ region $\left(6.5 \mathrm{Mg} \mathrm{ha}^{-1} \mathrm{yr}^{-1} \mathrm{C}\right)$, which contributed substantially to the increase in organic residue deposition and, consequently, to SOC stocks (Leite, 2001). Integrating information on use history, climate and soil characteristics by the Century model, Ardö \& Olsson (2003) obtained a good approximation of SOM cycling in relation to climate and management for soils under annual crops in the semiarid region of Sudan. Utilizing the Century model in a study carried out in the Brazilian Amazon, Cerri et al. (2004) found encouraging results for the TOC, total $\mathrm{N}$, microbial biomass $\mathrm{C}$ pools and ${ }^{13} \mathrm{C}$ as a function of management in a pasture chronosequence established in areas previously occupied by native Amazon forest.

The $\mathrm{C}$ stock in different soil Orders simulated by Century were mostly in close agreement with the observed values (Figure 3). Leite et al. (2004) also found small differences between simulated and observed values (0.4-7.0 \%) of SOC stocks for different management systems in Brazil. However, in another study of plowed soils in Hungary, Falloon \& Smith (2002) observed that the simulated were higher than the observed SOC values. In this study, for some soil orders such as the Inceptisols under eucalyptus and native forest in the regions of VG and IP, respectively, and Oxisol under eucalyptus in the $\mathrm{CO}$ region, the discrepancy of the simulated from the observed SOC stocks were larger $(-32.6 \%$ in the Inceptisol under eucalyptus in VG, $-33.8 \%$ in the Inceptisol under native forest in IP and $-38.7 \%$ in the Oxisol under eucalyptus in $\mathrm{CO}$, respectively). The lack of fit between modeled and measured data could have several possible explanations. Silver et al. (2000) noted that calibrating the model with clayey soils usually led to unexpected results when simulating coarser soils. Bricklemeyer et al. (2007) warned about hasty generalizations of relationships between soil texture and C stocks simulated by Century. Additionally, other limitations of the model must be considered e.g., the lack of explicit characterization of soil mineralogy, as well as the oversimplified plant/tree production model and monthly time step. More recent versions of the model allow simulating soil $\mathrm{pH}$ shift and more detailed plant growth sub-models with daily time steps. In tropical soils, the formation of the Al-SOM complex plays an important role preventing SOM mineralization, and higher acidity and aluminium contents are responsible for SOM stabilization (Mendonça, 1995; Meda et al., 2001). This calls for more detailed studies focused on the effects of soil mineralogy, $\mathrm{pH}$ and aluminium (and perhaps other cation) contents on SOM formation and stabilization under tropical conditions.

\section{CONCLUSIONS}

1. Four eucalyptus rotations led to an average increase of $0.28-0.42 \mathrm{t} \mathrm{ha}^{-1}$ year $^{-1}$ of $\mathrm{C}$ in soils previously under low-productivity pastures.

2 . The $\mathrm{C}$ stocks for quite distinct soils under native and planted forests simulated by the Century model are, in general, in close agreement to the measured values (root mean square error $-\mathrm{RMSE}=20.9$; model efficiency $-\mathrm{EF}=0.29$ ), but there are indications that the simulated and observed values differ, based on the identity model test.

3. Deviations of simulated from observed soil C stocks are not related to specific regions or soil orders, but are greater in soils with lower $\mathrm{C}$ content.

\section{ACKNOWLEDGEMENTS}

We would like to thank Dr. Fernando Palha Leite from CENIBRA for helping with the selection of the sampling sites and providing information on the studied areas. We are also indebted to CENIBRA for logistic support in the soil sampling period and to FAPEMIG and CNPq for continuous financial support for laboratory research. Finally, we would like to thank the anonymous reviewers, but especially the Associate Editor for the meticulous review of the manuscript and the very constructive suggestions.

\section{LITERATURE CITED}

ARDÖ, J. \& OLSSON, L. Assessment of soil organic carbon in semi-arid Sudan using GIS and the CENTURY model. J. Arid Environ., 54:633-651, 2003.

ARDÖ, J. \& OLSSON, L. Soil carbon sequestration in traditional farming of Sudanese drylands. Ecol. Manag., 33:318-329, 2004. 
BALIEIRO, F.C.; PEREIRA, M.G.; ALVES, B.J.R.; RESENDE, A.S. \& FRANCO, A.A. Soil carbon and nitrogen in pasture soil reforested with eucalyptus and guachapele. R. Bras. Ci. Solo, 32:1253-1260, 2008.

BARROS, N.F. \& COMERFORD, N.B. Sustentabilidade da produção de florestas plantadas na região tropical. In: ALVAREZ V., V.H.; SCHAEFER, C.E.G.R.; BARROS, N.F.; MELLO, J.W.V. \& COSTA, L.M., eds. Tópicos em ciência do solo. Viçosa, MG, Sociedade Brasileira de Ciência do Solo, 2002. v.2. p.487-592.

BAYER, C.; MARTIN-NETO, L.; MIELNICZUK, J.; PAVINATO, A. \& DIECKOW, J. Carbon sequestration in two Brazilian Cerrado soils under no-till. Soil Tillage Res., 86:237-245, 2006.

BODDEY, R.M.; JANTALIA, C.P.; CONCEIČÃO, P.C.; ZANATTA, J.A.; BAYER, C.; MIELNICZUK, J.; DIECKOW, J.; SANTOS, H.P. DENARDIN, J.E.; AITA, C.; GIACOMINI, S.J.; ALVES, B.J.R. \& URQUIAGA, S. Carbon accumulation at depth in Ferralsols under zerotill subtropical agriculture. Global Change Biol., 16:784795,2010

BRICKLEMYER, R.S.; MILLER, P.R.; TURK, P.J.; PAUSTIAN, K.; KECK, T. \& NIELSEN, G.A. Sensitivity of the century model to scale-related soil texture variability. Soil Sci. Soc. Am. J., 71, 784-792, 2007.

CERRI, C.C.; CERRI, C.E.P.; PAUSTIAN, K.; BERLATO, M.A.; BERNOUX, M.; VICTORIA, R.L. \& MELILLO, J.M. Modeling changes in soil organic matter in Amazon forest to pasture conversion with the Century model. Global Change Biol., 10:815-832, 2004.

CERRI, C.E.P.; EASTER, M.; PAUSTIAN, K.; KILLIAN, K.; COLEMAN, K.; BERNOUX, M.; FALLOON, P.; POWLSON, D.S.; BATJES, N.; MILNE, E. \& CERRI, C.C. Simulating SOC changes in 11 land use change chronosequences from the Brazilian Amazon with RothC and Century models. Agric. Ecosyst. Environ., 122:46-57, 2007.

CERRI, C.E.P.; PAUSTIAN, K.; BERNOUX, M.; VICTORIA, R.L.; MELILLO, J.M. \& CERRI, C.C. Modeling changes in soil organic matter in Amazon forest to pasture conversion with the Century model. Global Change Biol., 10:815-832, 2004.

CHEN, C.R.; XU, Z.H. \& MATHERSB, N.J. Soil carbon pools in adjacent natural and plantation forests of subtropical Australia. Soil Sci. Soc. Am. J., 68:282-291, 2004.

CHILCOTT, C.R.; DALAL, R.C.; PARTON, W.J.; CARTER, J.O. \& KING, A.J. Long-term trends in fertility of soils under continuous cultivation and cereal cropping in southern Queensland. IX. Simulation of soil carbon and nitrogen pools using CENTURY model. Austr. J. Soil Res., 45: 206 217, 2007.

DALMOLIN, R.S.D.; GONÇALVES, C.N.; DICK, D.P.; KNICKER, H.; KLAMT, E. \& KOGEL-KNABNER, I. Organic matter characteristics and distribution in Ferralsol profiles of a climosequence in southern Brazil. Europ. J. Soil Sci., 57:644-654, 2006.
DEL GROSSO, S.J.; PARTON, W.J.; MOSIER, A.R.; HARTMAN, J.; BRENNER, D.S.; OJIMA, D.S. \& SCHIMEL, D.S. Simulated interaction of soil carbon dynamics and nitrogen trace gas fluxes using the DAYCENT model. In: SHAFFER, M.J.; MA, L. \& HANSEN, S., eds. Modeling carbon and nitrogen dynamics for soil management. Boca Raton, Lewis Publishers, 2001. p.303-332.

DIECKOW, J.; MIELNICZUK, J.; KNICKER, H.; BAYER, C.; DICK, D.P. \& KÖGEL-KNABNER, I. Carbon and nitrogen stocks in physical fractions of a subtropical Acrisol as influenced by long-term no-till cropping systems and $n$ fertilisation. Plant Soil, 268:319-328, 2005.

DIECKOW, J.; MIELNICZUK, J.; KNICKER, H.; BAYER, C.; DICK, D.P. \& KÖGEL-KNABNER, I. Comparison of carbon and nitrogen determination methods for samples of a paleudult subjected to no-till cropping systems. Sci. Agric., 64:532-540, 2007.

DIELS, J.; VANLAUWE, B.; MEERSCH, M.K.V.D.; SANGINGA, N. \& MERCKX, R. Long-term soil organic carbon dynamics in a sub-humid tropical climate: ${ }^{13} \mathrm{C}$ data in mixed $\mathrm{C} 3 / \mathrm{C} 4$ cropping and modeling with ROTHC. Soil Biol. Biochem., 36:1739-1750, 2004.

DRUMOND, M.A. Alterações fitossociológicas e edáficas decorrentes de modificações da cobertura vegetal na Mata Atlântica, região do médio Rio Doce. Viçosa, MG, Universidade Federal de Viçosa, 1996. 73p. (Tese de Doutorado)

ELLERT, B.H. \& BETTANY, J.R. Calculation of organic matter and nutrients stored in soils under contrasting management regimes. Canadian J. Soil Sci., 75:529-538, 1995.

FALLOON, P. \& SMITH, P. Simulating SOC changes in longterm experiments with RothC and Century: model evaluation for a regional scale application. Soil Use Manag., 18:101-111, 2002.

FARIA, G.E. Produção e estado nutricional de povoamentos de Eucalyptus grandis, em segunda rotação, em resposta à adubação potássica. Viçosa, MG, Universidade Federal de Viçosa, 2000. 49 p. (Tese de Mestrado)

GALDOS, M.V.; CERRI, C.C.; CERRI, C.E.P.; PAUSTIAN, K. \& van ANTWERPEN, R. Simualtion of soil carbon dynamics under surgarcane with the century model. Soil Sci. Soc. Am. J., 73:802-811, 2009.

GAMA-RODRIGUES, E.F.; BARROS, N.F.; GAMARODRIGUEZ, A.C. \& SANTOS, G.A. Nitrogênio, carbono e atividade microbiana do solo em plantações de eucalipto. R. Bras. Ci. Solo, 29:893-901, 2005.

GIJSMAN, A.J.; OBERSON, A.; TIESSEN, H. \& FRIESEN, D.K. Limited applicability of the CENTURY model to highly weathered tropical soils. Agron. J., 88:894-903, 1996.

GRAYBILL, F.A. Theory and application of the linear model. Massachussets, Ouxburg Press, 1976. 704p.

GUO, L.B. \& GIFFORD, R.M. Soil carbon stocks and use change: a meta analysis. Global Change Biol., 8:345-360, 2002 . 
INSTITUTO BRASILEIRO DE GEOGRAFIA E ESTATISTICA - IBGE. Mapa de vegetação do Brasil. Rio de Janeiro, 1993.

IZAURRALDE, R.C.; WILLIAMS J.R.; McGILL, W.B.; ROSENBERG, N.J. \& JAKAS, M.C.Q. Simulating soil C dynamics with EPIC: Model description and testing against long-term data. Ecol. Modelling, 192:362-384, 2006.

JOURDAN, C.; SILVA, E.V.; GONÇALVES, J.L.M.; RANGER, J.; MOREIRA, R.M. \& LACLAU, J.P. Fine root production and turnover in Brazilian Eucalyptus plantations under contrasting nitrogen fertilization regimes. For. Ecol. Manag., 256:396-404, 2008.

KAISER, K.; EUSTERHUES, K.; RUMPEL, C.; GUGGENBERGER, G. \& KNABNER, K.I. Stabilization of organic matter by soil minerals investigations of density and particle-size fractions from two acid forest soils. J. Plant Nutr. Soil Sci., 165:451-459, 2002.

KAMONI, P.T.; GICHERU, P.T.; WOKABI, S.M.; EASTER, M.; MILNE, E.; COLEMAN, K.; FALLOON, P.; PAUSTIAN, K.; KILLIAN, K. \& KIHANDA, F.M. Evaluation of two soil carbon models using two Kenyan long term experimental datasets. Agric. Ecosyst. Environ., 122:95-104, 2007.

KELLY, R.H.; PARTON, W.J.; CROCKER, G.J.; GRACE, P.R.; KLIR, J.; KORSCHENS, M.; POULTON, P.R. \& RICHTER, D.D. Simulating trends in soil organic carbon in long-term experiments using the Century model. Geoderma, 81:75-90, 1997.

KIRSCHBAUM, M.U.F. \& PAUL, K.I. Modelling C and N dynamics in forest soils with modified version of the Century model. Soil Bio. Biochem., 34:341-354, 2002.

KLEINPAUL, I.S.; SCHUMACHER, M.V.; BRUN, E.J.; BRUN, F.G.K. \& KLEINPAUL, J.J. Suficiência amostral para coletas de serapilheira acumulada sobre o solo em Pinus elliottii engelm, Eucalyptus sp. e floresta estacional decídua. R. Árvore, 29:965-972, 2005.

LADEIRA, B.C. Crescimento, produção de biomassa e eficiência nutricional de Eucalyptus spp. sob três espaçamentos, em uma seqüência de idades. Viçosa, MG, Universidade Federal de Viçosa, 1999. 132p. (Tese de Mestrado)

LAL, R. Carbon sequestration in dry land ecosystems of West Asia and North Africa. Land Degrad. Develop., 13:45-59, 2002 .

LAL, R. Soil carbon sequestration to mitigate climate change. Geoderma, 123:1-22, 2004

LEITE, F.P. Crescimento, relações hídricas, nutricionais e lumínicas em povoamentos de Eucalyptus grandis em diferentes densidades populacionais. Viçosa, MG, Universidade Federal de Viçosa, 1996. 90p. (Tese de Mestrado).

LEITE, F.P. Relações nutricionais e alterações de características químicas de solo da Região do Vale do Rio Doce pelo cultivo do Eucalipto. Viçosa, MG, Universidade Federal de Viçosa, 2001. 72p. (Tese de Doutorado)

LEITE, H.G. \& OLIVEIRA, F.H.T. Statistical procedure to test the identity of analytical methods. Comm. Soil Sci. Plant Anal., 33:1105-1118, 2002.
LEITE, L.F.C. Compartimentos e dinâmica da matéria orgânica do solo sob diferentes manejos e sua simulação pelo Modelo Century. Viçosa, MG, Universidade Federal de Viçosa, 2002. 146p. (Tese de Doutorado)

LEITE, L.F.C.; MENDONÇA, E.S.; MACHADO, P.L.O.A.; FILHO, E.I.F. \& NEVES, J.C.L. Simulating trends in soil organic carbon of an Acrisol under no-tillage and discplow systems using the Century model. Geoderma, 120:283-295, 2004.

LEMMA, B.; KLEJA, D.B.; NILSSON, I. \& OLSSON, M. Soil carbon sequestration under different exotic tree species in the Southwestern highlands of Ethiopia. Geoderma, 136:886-898, 2006.

LIMA, A.M.N.; SILVA, I.R.; NEVES, J.C.L.; NOVAIS, R.F.; BARROS, N.F.; MENDONCA, E.S.; SMYTH, T.J.; MOREIRA, M.S. \& LEITE, F.P. Soil organic carbon dynamic following afforestation of degraded pasture with eucalyptus in southeastern Brazil. For. Ecol. Manag., 235:219-231, 2006.

LIMA, A.M.N.; SILVA, I.R.; NEVES, J.C.L.; NOVAIS, R.F.; BARROS, N.F.; MENDONÇA, E.S.; DEMOLINARI, M.S.M. \& LEITE, F.P. Frações da matéria orgânica do solo após três décadas de cultivo de eucalipto no Vale do Rio Doce-MG. R. Bras. Ci. Solo, 32:1053-1063, 2008.

MEDA, A.R.; CASSIOLATO, M.E. \& PAVAN, M.A. Alleviating soil acidity through plant organic compounds. Braz. Arch. Biol. Technol., 44:185-189, 2001.

MENDHAM, D.S.; CONNELL, A.M. \& GROVE, T.S. Organic matter characteristics under native forest, long-term pasture, and recent conversion to eucalyptus plantations in Western Australia: Microbial biomass, soil respiration, and permanganate oxidation. Austr. J. Soil Sci., 40:859872,2002 .

MENDHAM, D.S.; HEAGNEY, E.C.; CORBEELS, M.; O'CONNELL, A.M.; GROVE, T.S. \& McMURTRIE, R.E. Soil particulate organic matter effects on nitrogen availability after afforestation with Eucalyptus globulus. Soil Biol. Biochem., 36:1067-1074, 2004.

MENDONÇA, E.S. Oxidação da matéria orgânica e sua relação com diferentes formas de alumínio de Latossolos. R. Bras. Ci. Solo, 19:25-30, 1995.

MENEZES, A.A. Produtividade do eucalipto e sua relação com a qualidade e a classe de solo. Viçosa, MG, Universidade Federal de Viçosa, 2005. 98p. (Tese de Doutorado)

METHEREL, A.K.; HARVING, L.A.; COLE, C.V. \& PARTON, W.J. Century: Soil organic matter model environment. Technical documentation agrosystem version 4.0. USDAARS, Fort Collins, 1994.123p. (Great Plains System Research Unit. Technical Report, 4)

MORRIS D.M.; KIMMINS, J.P.; DAN, I. \& DUCKERT, R. The use of soil organic matter as a criterion of the relative sustainability of forest management alternatives: A modeling approach using FORECAST. For. Ecol. Manag., 94:61-78, 1997.

MOTAVALLI, P.P.; PALM, P.C.A.; PARTON, W.J.; ELLIOT, E.T. \& FREYS, S.D. Comparison of laboratory and modeling simulation methods for estimating soil carbon pools in tropical forest soils. Soil Biol. Biochem., 26:935944, 1994 
NIMER, E. Climatologia do Brasil. Rio de Janeiro, Departamento de Recursos Naturais e Estudos Ambientais/IBGE, 1989.

O'BRIEN, N.D.; ATTIWILL, P.M. \& WESTON, C.J. Stability of soil organic matter in Eucalyptus regnans forests and Pinus radiata plantations in southeastern Austr. For. Ecol. Manag., 185:249-261, 2003.

PARTON, W.; TAPPAN, G.; OJIMA, D. \& TSCHAKERT, P. Ecological impact of historical and future land-use patterns in Senegal. J. Arid Environ., 59:605-623, 2004.

PARTON, W.J.; SCHIMEL, D.S.; COLE, C.V. \& OJIMA, D.S Analysis of factors controlling soil organic levels of grasslands in the Great Plains. Soil Sci. Soc. Am. J., 51:1173-1179, 1987.

PARTON, W.J.; SCURLOCK, J.M.O.; OJIMA, D.S.; GILMANOV, T.G.; SCHOLES, R.J.; SCHIMEL, D.S.; KIRCHNER, T.; MENAUT, J.C.; SEASTEDT, T.; MOYA, E.G.; KAMNALRUT, A. \& KINAMARIO, J.I. Observations and modelling of biomass and soil organic matter dynamics for the grassland biome worldwide. Global Biogeochem. Cycles, 7:785-809, 1993.

PARTON, W.J.; STEWART, J.W.B. \& COLE, C.V. Dynamics of $\mathrm{C}, \mathrm{N}, \mathrm{P}$ and $\mathrm{S}$ in grassland soils: A model. Biogeochemistry, 5:109-131, 1988.

PAUL, K.I. \& POLGLASE, P.J. Prediction of decomposition of litter under eucalypts and pines using the FullCAM model. For. Ecol. Manag., 191:73-92, 2004.

PHILLIPS, O.L.; LEWIS, S.L.; BAKER, T.R.; CHAO, K-J. \& HIGUCHI, N. The changing Amazon forest. Phil. Trans. R. Soc. B., 363:1819-1827, 2008.

POLYAKOV, V. \& LAL, R. Modeling soil organic matter dynamics as affected by soil water erosion. Environ. Inter., 30:547- 556, 2004.

SCHULTEN, H.R. \& LEINWEBER, P. New insights into organic-mineral particles: composition, properties and models of molecular structure. Biol. Fert. Soils, 30:399432,2000 .

SILVER, W.L.; OSTERTAG, R. \& LUGO, A.E. The potential for carbon sequestration through reforestation of abandoned tropical agricultural and pasture lands. Rest. Ecol., 8:394-407, 2000.
SMITH, J.U.; SMITH, P. \& ADDISCOTT, T. Quantitative methods to evaluate and compare soil organic matter (SOM) models. In: POWLSON, D.S.; SMITH, P. \& SMITH, J.U., eds. Evaluation of soil organic matter models using existing, long-term datasets. Berlin, Springer-Verlag, 1996. p.181-200. (NATO ASI Series I., v. 38)

SMITH, P.; SMITH, J.U.; POWLSON, D.S.; McGILL,W.B.; ARAH, J.R.M.; CHERTOV, O.G.; COLEMAN, K.; FRANKO, U.; FROLKING, S.; JENKINSON, D.S.; JENSEN, L.S.; KELLY, R.H.; KLEIN-GUNNEWIEK, K.; KOMAROV, S.A.; LI, C.; MOLINA, J.A.E.; MUELLER, T.; PARTON, W.J.; THORNLEY, J.H.M. \& WHITMORE, A.P. A comparison of the performance of nine soil organic matter models using datasets from seven long-term experiments. Geoderma, 81:153-225, 1997.

SOARES, P.; TOME, M.; SKOVSGAARD, J.P. \& VANCLAY, J.K. Evaluating a growth model for forest management using continuous forest inventory data. For. Ecol. Manag., 71:251-265, 1995.

TORNQUIST, C.G.; MIELNICZUK, J. \& CERRI, C.E.P. Modeling soil organic carbon dynamics in Oxisols of Ibirubá (Brazil) with the Cenutry Model. Soil Tillage Res., 105:3343, 2009.

TURNER, J. \& LAMBERT, M. Change in organic carbon in forest plantation soil in eastern Australia. For. Ecol. Manag., 133:231-247, 2000.

VESTERDAL, L.; RITTER, E. \& GUNDERSEN, P. Change in soil organic carbon following afforestation of former arable land. For. Ecol. Manag., 169:137-147, 2002.

WENDLING, B. Carbono e nitrogênio no solo sob diferentes usos e manejos e sua modelagem pelo Century. Viçosa, MG, Universidade Federal de Viçosa, 2007. 122p. (Tese de Doutorado)

WOOMER, P.L.; MARTIN, A.; ALBRECHT, A.; RESCK, D.V.S. \& SCHARPENSEEL, H.W. The importance and management of soil organic matter in the tropics. In: WOOMER, P.L. \& SWIFT, M.J., eds. The biological management of tropical soil fertility. Chichester, Wiley, 1994. p.47-80.

YEOMANS, J.C. \& BREMNER, J.M. A rapid and precise method for routine determination of organic carbon in soil. Comm. Soil. Sci. Plant Anal., 13:1467-1476, 1988. 